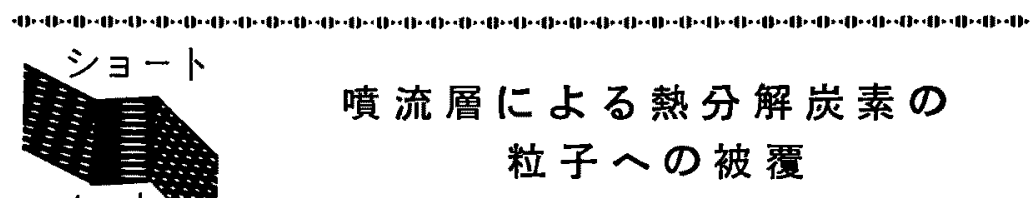

武田 宏*,山本 寛*

（1975年 12 月26日 受 理）

\section{Pyrocarbon Coating on Particles by Spouted Bed}

By Hiroshi TAKEDA and Yutaka YAMAMOTO
造用被覆装置の基整研究と して両装置の比較を行なっ たものである。

1. 実験装量および方法 2 種の反応管を用いてブ ロパンガスの熱分解を行 い, 希釈ガスとして $\mathrm{N}_{2} カ ゙$ スを用いた。 $\mathrm{N}_{2}$ ガスとプロ パンガスを增外で混合して 単一ノズルから吹き込む型 の反応管および実験装置を Fig.1(a)と(b)に示す。 Fig.1(c) に噴流化ガスと

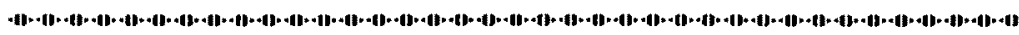
プロパンガスの入口を分離した型の反応管の円錐部を

KEYWORDS: pyrocarbon, coated fuel particles, spouted bed, coating apparatus, HTGR type reactors, experiment, propane gas, high temperature, coating, camparative evalation

熱分解炭素(PyC)の粒子への被覆はメタン,プロパ ン,フセチレン等の炭化水素ガスを流動㬝中で熱分解 させて行われる。このPyCの性質は原料ガスの種類， 供給量, 温度条件, 粒子流動化状態などの諸因子に影锌 されることが知られている(1)。

被覆装置に関する研究は，ORNL でU中 Th の酸 化物江炭素を多重層被覆する目的で種々の装監による 被嘌実験が行われた(2)。この結果に上ると，ロータリ 一ドラム性原料ガスと粒子との接触が悪く被覆速度が 非常に小さく，エントレインベッドは層内に円筒部分 があるためそれへの炭素の付着が問題になる。流動層 に上る被覆が良いと結諭し，ガスを多孔板を通した型 と単一フズルから吹込んた型との比校も行なって多 孔板の目詰りを考虑すると，後者の方が倀れていると している。すなわち，噴流層の形式で原料ガスを希䣋ガ スと混合して単一ノズルから層内に送り込んでいる。 噴流層で嘖流化ガスと原料ガスを混合させないで層 底部に送り込む方法の研究も行わ机ている(3)。この方 法はノズル中心部に噴流化ガスを流し，ノズルの周囲 を原料ガスを流して凮内に送るむのである。この研究 では,バッブリング状態で被覆するのが最も大きな被 覆速度が得られると結論している。

本報は，噴流層による $\mathrm{PyC}$ の被覆実験を 2 種の型 の装置を用いて行なった。すなわち，炭化水素を希䐆 ガスとノズル手前で混合させて供給する場合と，噴流 化ガスを炭化水素ガスと分離して炭化水素ガスをノズ ルから数 $\mathrm{cm}$ 層内に入った円錐部分内壁に供給する場 合の 2 種の噴流層による装置であり, HTGR 然料製 示す。反応ガスはノズル位固より52 mm 上力の円環状 部分から送り出される。Fig.1(a)に示した型を反応管 1，Fig.1(c)の型を反応管 2 とすると，両反応管ともカ ラム径 $100 \mathrm{~mm} \phi$ 円錐部角度 $30^{\circ}$ であり，ノズル径は反

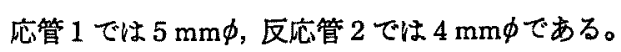

粒子としてアルミナ粒子を用い，高温での焼結を避

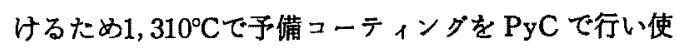
用した。粒子径は780〜820 $\mu$ ，1回の装荷粒子量は $400 \mathrm{~g} て ゙ ，$ 実験により条件を変えた被覆を同一粒子に 行なった場合もあり，多重被覆になる。

実験方法は，まず $\mathrm{N}_{2}$ ガスを装置に流しててルミナ 粒子を装荷する。直流電源電圧を上昇させて黒鉛七一 ターを加熱して反応管を高温にし，温度を目的温度で 一定に保つ。温度の測定は反応管外壁をノズルから27 $\mathrm{cm}$ 上方の親き空を通して観察し，光高温計で調べる。 反応管 1 では， $\mathrm{N}_{2}$ ガス流量 $35 \mathrm{l} / \mathrm{min}$ の条件で一定 温度に保った後,プロパンガスを4.0 10.6l/minの 範围で混合させて被覆を開始させる。

反応管 2 では，中心のノズルから $30 \mathrm{l} / \mathrm{min} の \mathrm{~N}_{2}$ ガ スを導入し，反応がス送入口には $5 l / m i n の \mathrm{~N}_{2}$ ガス を混合して㬝内温度を一定保り，反応がス送入口側 の $5 \mathrm{l} / \mathrm{min}$ の $\mathrm{N}_{2}$ ガスに 4.0〜10.6 l/minのプロパン ガスを混合して被覆を開始させる。被覆時間は20 90 $\min$ である。

\section{2. 実駼結果および考察}

両実験とる $1,550^{\circ} \mathrm{C}$ 以下の温度で被覆を行なっ た。これはアルミナ粒子を用いているためである。被 覆厚みは被覆粒子をエポキシ樹脂中に埋め込み，それ

* 東京大学工学部原子力工学科 (Dept. of $\mathrm{Nucl}$. Eng., Univ. of Tokyo) 


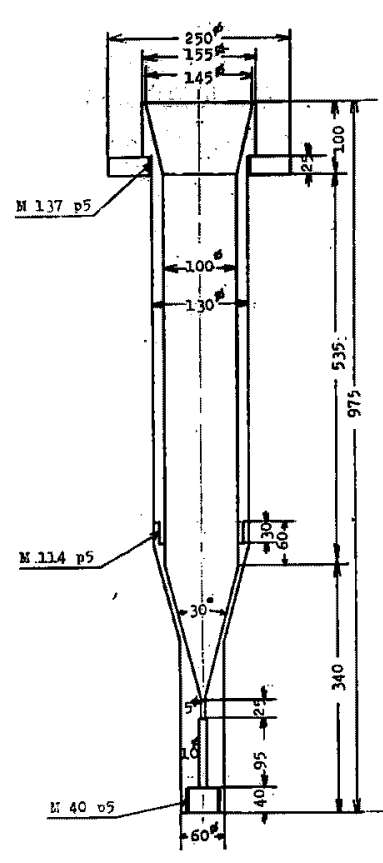

(a) Graphite spouted bed (reactor tube 1)

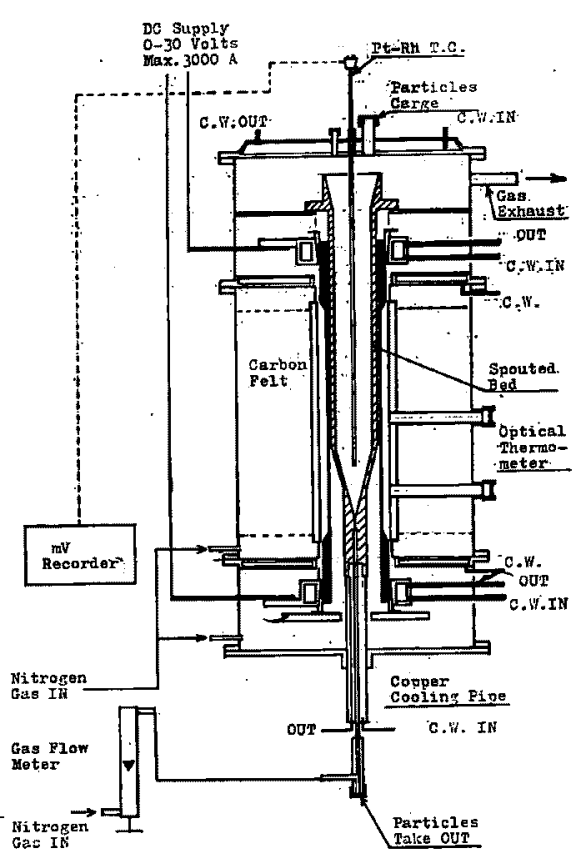

(b) Experimental apparatus for PyC coating

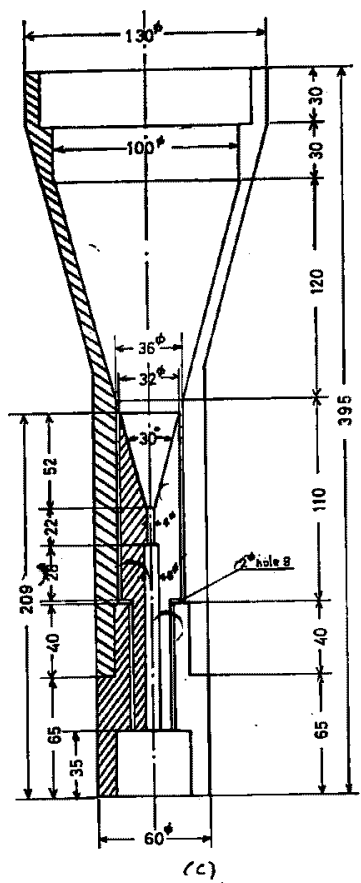

(c) Cone part of graphite spouted bed (reactor tube 2)

Fig. 1 Schematic diagram

を研磨し金属影微鏡で測定した。

Table 1 に被覆条件, 被覆速度(c.r.) 抢上び蒸着效率 (d.e.)を示す。Run1～5は反応管1によるもので, Run 6 15は反応管 2による結果である。被覆速度は 単位時間当りの被覆厚みの增加量を $(\mu / \mathrm{hr})$ で表わし,

蒸着効率は被覆時間内に供給されるプロパンガスが 全部熱分解する時の炭菜重量に対する粒子に被覆され た岸素重量の比として表わしている。炭素の被覆重量 は被覆粒子試料を約 $2 \mathrm{~g}$ バーナーで燒いて脱被覆を行 い, その前後の重量差から求めた。

温度はノズル位直から $27 \mathrm{~cm}$ 上方の反応管外壁温度 で，層内温度はこれより $200^{\circ} \sim 300^{\circ} \mathrm{C}$ 低くなる。プロ パンガスを供給し始めると温度は吸熱反応のため低く なる。表中の温度(1)は供給前, 温度(2)は前後の平均值 を示している。

被覆速度は温度上界とプロパソガス供給量の増加に 従って大きくなる。反応管 1 では温度が $1,300^{\circ} \mathrm{C}$ 付近 では非常に小さいが， $1,500^{\circ} \mathrm{C}$ 付近で急速炕大きくな る傾向が見られる。一方, 反応管 2 ではプロパンガス 供給量にはほ比例した被覆速度 (C.R.)になり, 次の ような関保になる。

$$
\text { C.R. } \propto F\left(T-T_{0}\right)
$$

Table 1 Comparison of coating rate (C.R.) under some coating conditions

\begin{tabular}{|c|c|c|c|c|c|c|c|}
\hline \multirow{2}{*}{ Run } & \multicolumn{3}{|c|}{$\begin{array}{l}\text { Feed rate } \\
(l / \mathrm{min})\end{array}$} & \multicolumn{2}{|c|}{ Temp. $\left({ }^{\circ} \mathrm{C}\right)$} & \multirow{2}{*}{$\begin{array}{c}\text { c.r. } \\
(\mu / \mathrm{hr})\end{array}$} & \multirow{2}{*}{$\begin{array}{l}\text { d.e. } \\
(\%)\end{array}$} \\
\hline & $\mathrm{C}_{3} \mathrm{H}_{8}$ & $\mathrm{~N}_{2}$ & $\mathrm{~N}_{2}$ & $(1)^{\dagger}$ & $(2) t$ & & \\
\hline 1 & 6.4 & - & 35 & 1,298 & 1,288 & 3.3 & 0.8 \\
\hline 2 & 6.4 & - & 35 & 1,440 & 1,435 & 30 & 8.3 \\
\hline 3 & 6.4 & - & 35 & 1,525 & 1,509 & 83 & 28 \\
\hline 4 & 4.0 & - & 35 & 1,540 & 1,528 & 66 & 33 \\
\hline 5 & 10.6 & - & 35 & 1,540 & 1,468 & 125 & 44 \\
\hline 6 & 4.0 & 5.0 & 30 & 1,298 & 1,292 & 11 & 9.2 \\
\hline 7 & 6.4 & 5.0 & 30 & 1,298 & 1,289 & 23 & 6.6 \\
\hline 8 & 6.4 & 5.0 & 30 & 1,450 & 1,423 & 83 & 35 \\
\hline 9 & 6.4 & 5.0 & 30 & 1,320 & 1,300 & 26 & 12 \\
\hline 10 & 6.4 & 5.0 & 30 & 1,545 & 1,530 & .135 & 43 \\
\hline 11 & 4.0 & 5.0 & 30 & 1,300 & 1,298 & 18 & 10 \\
\hline 12 & 4.0 & 5.0 & 30 & 1,410 & 1,408 & 50 & 30 \\
\hline 13 & 4.0 & 5.0 & 30 & 1,520 & 1,512 & 75 & 45 \\
\hline 14 & 6.4 & 5.0 & 30 & 1,517 & 1,504 & 115 & 32 \\
\hline 15 & 10.6 & 5.0 & 30 & 1,525 & 1,511 & 188 & 65 \\
\hline
\end{tabular}

$\dagger$ These were measured by optical thermameter through a view finder of $27 \mathrm{~cm}$ distance from gas inlet nozzle, (1) is the temperature at the beginning of coating, and (2) is the average of the temperature during coating. 
ここで, $T$ : 温度， $F$ : 供給速度

蒸着効率はプロパンガスが係内で完全に熱分解して いるとは限らないため目安に過ぎないが，この值も被 覆速度と同じ傾向が見られる。

両反応管を比較すると，同じプロパン供給速度では 反応管 2 の方が被覆速度が大きく，この傾向は温度が 低いはど著しい。例えば $6.4 \mathrm{l} / \mathrm{min}$ の供給速度では $1,288^{\circ} \mathrm{C}$ て 7 倍, $1,435^{\circ} \mathrm{C}$ で 3 倍， $1,509^{\circ} \mathrm{C}$ て 1.5 倍反応 管1より大きい。の理由として次のことが考光られ る。

噴流層は層中心部にガス吹抜け領域があり，そのま わりに円環状に粒子の沈降する領域が存在する。粒子 の被覆はこの円環部でのプロパンガスと粒子の接触が 支配すると考えられる。本案験の反応管 1 では噴流部 を吹き拔けるプロバンガスが多く，反応管 2 では円環 部にプロパンガスを送り込んでいるため有効に粒子と 接触する。また，層の温度が高い部分に反応管 2 では ガスを送っているのに対し，反応管 1 では一番低い領 域に送り込む形になっている。以上が反応管 2 の方が 被覆速度の大きくなる原因である。

本実験の PyC の性質を $\mathrm{Cu}$ の特性 X線によりX線回
折で調べると，実験条件内ではビーク幅は広いが $2 \theta=$ $25.4^{\circ}$ の位㯰にビークが現れている。これに相当する 層面間隔は3.51 ̊となる。一般に黒鉛で3. $35 \AA$ ，無定

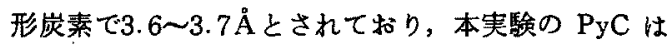
無定形に近い性質と考えられる。なお，PyCの等方 性, 密度は重要な因子であり，これらの因子と本被覆 装置との関係については今後の実験により検討する。

\section{結 害}

2 種の形の櫴流層による PyC の粒子への被覆実駼 を行い，両者の比較を行なった。

プロパンガスを円錐部内壁がら供給し中心部にスス ルから噴流化ガスを供給する型の喷流層の方が，ズ ルからプロパンガスを噴流化ガスと一緒にして供給す る型の噴流層より数倍大きな被覆速度が得られること を明らかにした。

\section{一尝考文献一}

(1) Bokros, J.C.: "Chemistry and Physics of Carbon", (ed. D.H. Walker), Vol. 5, I (1968), Marcel Dekker, N.Y.

(2) WYMER, R.G., LOTTS, A.L.: ORNL-4275, (1969).

(3) Wallroth, C.F., GYarmati, E., Nickel, H. : Chem. Ing. Tech., 43, 1298 (1971).

\section{「昭和50年秋の分科会」予稿菒}

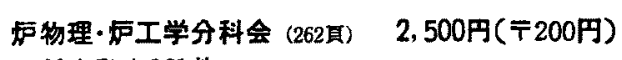
研究発表261件

核然料・原材料分科会 (84) 研究器表84件 化学·化学工学分科会 (58目) 研究発表57件

保建物理分科会 (20而) 研究発表19件

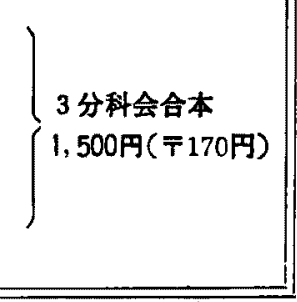

\section{「昭和51年年会」要旨集} 売 切れ!

第 I 分冊(邩物理・炉工学) (p.268)

研究発表226件，特別講演 1 件，棇合講演 2 件 総合報告 3 件

第 II分冊(燃料材料，化学·化工，保物) (p.240) 研究発表134件,特別講演 1 件, 総合䛾演 2 件 線合報告 3 件 